\title{
Role of Rural Women in Post-harvest Handling and Export of Jasmine Flowers
}

\author{
Barad, A. V.*, Madhuri Gandamalla, Pooja Maheta \\ College of Agriculture, Junagadh Agricultural University (J. A. U.), India
}

Copyright $\bigcirc 2017$ by authors, all rights reserved. Authors agree that this article remains permanently open access under the terms of the Creative Commons Attribution License 4.0 International License

\begin{abstract}
Among the loose flowers the jasmine is very important and remunerative crop. Multiuse of these flowers like used as loose flowers as well as for extraction of essential oil makes it more remunerative. The Indian $J$. grandiflorum compared favorably with that of Spanish jasmine, both in yield and quality of oil. The flower is in high demand in places such as Mumbai, besides the coastal region. Local traders collect jasmine flowers from the farmers directly. Jasmine begins to flower in the second year onwards or sometimes even earlier, but economic yields are obtained only from the third year. Prices are decided at the auction centre. Poor women in other cities across India can adopt jasmine cultivation as an activity to earn income and eradicate poverty. Moreover, this activity takes place early morning and the women are free to undertake other work during the day. Though the jasmine is a high capital intensive crop but its cultivation is quite profitable. The investment in jasmine is economically feasible and financially sound. Jasmine is labour-intensive crop, it provide more man days labour per year.
\end{abstract}

Keywords Jasmine Species, Cultivation, Marketing, Value Addition, Rural Women, Upliftment

\section{Introduction}

The jasmine is an important flower crop grown in open field throughout India. Rural women are involved in home scale cultivation, post-harvest management, value addition, marketing and export promotion of this crop. Jasmine is one of the oldest fragrant flowers cultivated by man. The name Jasmine is derived from the Persia "yasmin", meaning a gift from God. They are traditionally important flowers not only as fresh flowers but also as source of high grade perfume oil. Mention of jasmine is there in ancient Indian literature like Kamasutra (AD 300-400) and Mahabharatha (500 BC). In Kamasutra virtuous wife should plant jasmine in her garden, with other shrubs. The odor of jasmine flowers cannot be imitated by any known synthetic chemical or natural isolates, thus giving it a unique status in the perfume world. Widely cultivated for its flowers, jasmine is enjoyed in the garden, as a house plant, and as cut flowers.

For the past many centuries, they have adorned the gardens of Central Asia, Afghanistan, Iran, Nepal and many other tropical and subtropical countries. In India, they are cultivated throughout the country over an estimated area of more than 8000 ha. India exports jasmine to the USA, Gulf countries (Dubai), Australia, France, Canada, England, Sri Lanka, Singapore, Malaysia, etc.

Jasmine plants are grown as both climbers and shrub. The world famous jasmine oil is extracted from flowers of the Spanish jasmine (Jasminum grandiflorum). The Carasse region of France supplies the best quality jasmine perfume to the international perfume trade. France supplies $50 \%$ of the estimated world production of $5000 \mathrm{~kg}$ of jasmine concrete to the international perfumery trade. Belgium, Netherlands, Italy, Algeria, Turkey, Morocco and Tunisia are the other important jasmine oil producing countries of the world jasmine are traditionally used for decorating hair. Main concrete importers countries are France, Germany and Belgium.

Jasmine flowers owe their fragrance to a volatile oil present in the epidermal cells of the inner and outer surface of the petals and sepals. The international market prices for jasmine concrete and absolute are around Rs. 12000/kg. and Rs. 19000/kg., respectively. Extraction of oil from jasmine is yet to be exploited to its fullest potential in India. Research wok has shown that Indian jasmines give good quality oil comparable with that of French Jasmine. Among the scented species, J. angustifolium, J. officinale, J. humile, and $J$. pubescens were useful. The Indian $J$. grandiflorum compared favorably with that of Spanish jasmine, both in yield and quality of oil.

\section{Species and Cultivars}

Jasmine shrubs reach to a height of 10-15 feet, growing approximately 12-24 inches per year. Jasmine leaves are 
either evergreen or deciduous. A Jasmine leaf is arranged in opposite in most species, leaf shape is simple, trifoliate or pinnate with 5-9 leaflets, each up to two and half inches long. The Jasmine stems are slender, trailing, green, glabrous, angled, and almost 4-sided. Most of the Jasmine species bear white flowers, which are about 1 inch in size. Classification of jasmine is confusing because of existence of synonyms. Although up to 200 species were listed by several authors, about ninety species are believed to be true in existence. Some of the important species are described below (Bhattacharjee and De, 2005)

J. grandiflorum: It is a native of India and popularly called 'Royal Spanish', 'Catalonian', or Italian Jasmine. The leaves are shining dark green with 5-7 leaflets. This is twining shrub with pendulous branches. Flowers are white with a purplish tinge underneath and highly scented. Varieties coming under this are pinkpin, Co-1, pitchi, thimmapuram, Lucknow etc. J. grandiflorum is grown for extraction of perfume.

J. sambac: The Arabian jasmine or Tuscan jasmine $(J$. sambac) is a native of India. It is a dwarf growing shrub with almost sessile leaves having wavy margins. It is also possible to grow it as a short climber. The highly scented flowers are borne on clusters of 3-12. The flowers may be single, semi double or perfectly double. The species flowers mainly during summer and rainy seasons, but several other flushes during other parts of the year are quite common. Some promising cultivars are Gundumalli, Motia, Virupakshi, Soojimalli, Madanban and Ramabanam.

J. auriculatum: It is also a creeping species has smooth foliage with three leaflets. The flowers are white, single or double and are borne in clusters having many flowers. High yielding cultivars are Parimullai, CO-1, Long point, Long round, Short point, and Short round.

J. multiflorum: It is non-scented, but attractive, the hardiest and the least affected by pest and diseases. Kakada is an improved culture and a natural variant 'Bubescens' has got fragrance. In a trial for evaluating jasmine species and varieties for hillzone, $j$. multiflorum, Kakada recorded the highest yield (8987.4/ha)

\section{Case Study of Jasmine Cultivation}

Cultivation of jasmine (Jasminum sambac) started in Shankarapura town in Udupi district, Karnataka state about 100 years ago. It was promoted by a Christian priest to help poor women in the area to earn income. It is found extensively in Bhatkal, Udupi, Dakshina Kannada and Uttara Kannada, and has been found more economically viable among all the three varieties. The flower is in high demand in places such as Mumbai, besides the coastal region. Every home in this region has 0.5 to 1 acre $\left(2,000\right.$ to $\left.4,000 \mathrm{~m}^{2}\right)$ of land in front of the house for Jasmine growing'. Local traders collect jasmine flowers from the farmers directly. Prices are decided at the auction centre in Shankarpura daily. According to local women, who works at the Jasmine Land
Flower Stall in Udupi, the price of one "atte" (800 flowers make one chendu and four chendus make one "atte") of jasmine was hovering between Rs. 300 and Rs. 400 till October. Since then, the price of one "atte" of jasmine has been hovering around Rs. 700. It touched Rs. 1,000 an "atte" during October end. When poor women in Shankarapura town have successfully used floriculture as an income generating activity, poor women in other cities across India can adopt jasmine cultivation as an activity to earn income and eradicate poverty. Moreover, this activity takes place early morning and the women are free to undertake other work during the day.

Growing Jasmine Flowers: Seed propagation is usually practiced for hybridization programs only. Layering and cutting are the main propagation methods. Simple and compound layering methods are followed. The best season is during June-July to October-November. Rooted layers will be ready in 100-120days. Cutting is the easiest method of propagation. Certain factors like rooting media, type of cutting, environmental conditions and so on influence rooting of cuttings. IBA ( $4000 \mathrm{mg} / 1$ litre) proved to be the best for inducing rooting of hard wood cutting. These are hardy plants and with irrigation can be grown in a wide range of soils and climate. The best soil type suitable for their growth is sandy loam or clayey loam. Once planted, jasmine occupies the soil for 10-15 years. Hence, thorough land preparation is essential. The best time for planting is May-June. Pits of size $45-60 \mathrm{~cm}^{3}$ as taken filled with topsoil after mixing with $15 \mathrm{~kg}$ well rotten FYM. Planting distance depends on species and cultivars and also on soil and environmental conditions.

\begin{tabular}{|c|c|}
\hline Species & Planting distance \\
\hline J. grandiflorum & $2.0 \mathrm{~m} \times 1.3 \mathrm{~m}$ \\
\hline J. sambac & $0.60 \mathrm{~m} \times 0.90 \mathrm{~m}$ \\
\hline J.auriculatum & $1.8 \mathrm{~m} \times 1.8 \mathrm{~m}$ \\
\hline J.multiflorum & $1.8 \mathrm{~m} \times 1.8 \mathrm{~m}$ \\
\hline
\end{tabular}

Nutrients are applied directly to the soil or as foliar spray. Application of $100 \mathrm{~g} \mathrm{~N}, 150 \mathrm{~g} \mathrm{P}_{2} \mathrm{O}_{5}$ and $100 \mathrm{~g} \mathrm{~K}_{2} \mathrm{O}$ per plant per year in J. grandiflorum and J. auriculatum are found best. Flower yield further increases with application of zinc sulphate $10 \mathrm{~kg} / \mathrm{ha}$, magnesium sulphate $40 \mathrm{~kg} / \mathrm{ha}$ and borax 5 $\mathrm{kg} / \mathrm{ha}$. Manures and fertilizers are applied after one week of pruning once in a year, or in two split doses, once in winter and another on the advent of monsoon.

Pruning: It is an important practice to manipulate growth and flowering as it influences growth, flowering, bud initiation differentiation and ultimately the flower production. It is usually done by cutting shoots of height $45 \mathrm{~cm}$ from the ground level. The cut end must be smeared with Bordeaux paste to prevent infection. J. auriculatum, J. sambac and $J$. multiflorum are pruned in the third week of November and $J$. grandiflorum during mid-December January. Some chemical defoliants are also used for pruning e.g.: Paraquat dichloride, Pentachloro phenol, Sodium chloride etc. Iruvatchi a cv. 
ofJasmine sambac sprayed with paclobutrazol (10ppm) at monthly intervals twice after pruning gave the highest flower number and flower yield weed control [4].

Weed Control: Manual Weed is effective, but expensive, Use of weedicides like gramoxone is also practice, and Mulching also reduces weed population.

Harvest and Yield: Jasmine begins to flower in the second year onwards or sometimes even earlier, but economic yields are obtained only from the third year. Generally, they produce maximum flowers till $12-15$ years, and then start declining in the yield. Flowers are harvested either in the evening or early in the morning when the buds are fully developed but still unopened. Pluckers collect the flowers in a bag hanging from their shoulders. For extraction of jasmine concrete, the fully opened flowers are harvested early in the morning between 6-8 a.m. Care should be taken to see that the flowers are not rough handled, wrinkled and damaged during harvest and transit.

Post-harvest Treatment: Flowers last for 12-48 hours depending upon the species. Shelf life can be enhanced from 24-48 hours by soaking the flowers in any chemical solutions, namely sucrose $(1 \%)$, boric acid $(0.5 \%)$, copper sulphate $(0.1 \%)$, aluminium sulphate $(0.1 \%)$ or silver nitrate $(0.1 \%)$ remains fresh for two days without losing the fragrance. Cold treatment also enhances the longevity of flowers. Packaging jasmine flowers in polyethylene bags (200 guage) without ventilation is beneficial in maintaining higher quality and extending the shelf life of flowers. Storing the packed flowers in cool chamber $\left(8^{0} \mathrm{C}\right)$ further enhances the flower quality and shelf life. Quality parameters are fragrance, color development, freshness of the flowers, flower opening and shelf life. Shelf life of jasmine flowers, from harvest at tight bud stage to withering, varies inherently between species, that is Jasminum multiflorum( 48-60 hours), Jasminum sambac (28-30 hours), Jasminum auriculatum (28-30hours), Jasminum grandiflorum (24 hours). Different post-harvest management practices like pre-cooling, packaging, chemical treatment, cold storage, etc. have been found to be beneficial in extending the shelf life of jasmine flowers, increasing valuable time available for airlifting to foreign markets [3].

Packing: Flower buds are graded according to the corolla tube length, bud size, shape and freshness. Corrugated cardboard boxes are the proper packaging material for distant markets. While bamboo baskets may also be used for local market. Packaging should be functional, economical and attractive besides being acceptable in the markets. Harvested flowers should be given cold treatment before packing. For export packaging (CFB) for Dubai the Jasmine fresh flowers treated with boric acid@4\% are packed in ventilated corrugated fiber board (CFB) boxes. They are made ready for airlifting to Dubai market. While the export packaging (TC Boxes) for the USA, jasmine fresh flowers tied into strings treated with boric acid @ 4\% and cut into $15 \mathrm{~cm}$. Strings are packed in small boxes lined with butter paper and small boxes placed in thermocol boxes lined with aluminum foil, ice gel placed over small boxes which are covered with aluminum foil, and are ready for airlifting to USA market.

Value Added Products: Jasmine flower oil, extracted from the two species Jasminum officinale and grandiflorum, is used in high-grade perfumes and cosmetics, such as creams, oils, soaps, and shampoos. Jasmine is used for decorations for various occasions like wedding and anniversary. It is used for making perfumes and incense. The flowers are used for flavoring tea and black tea. It is used for making oils which are used in Aromatherapy. It oil extracts are used in beauty products for rejuvenate your skin. It known to be heavily fragrant flower also helps to lift the mood for people who undergo emotional depression. It helps in relieving stress by its fragrance and encourages the individual to relax and live healthy. As medicinal uses, are the Jasmine flowers, are used for removing intestinal worms and is also used for jaundice and venereal diseases. The flower buds are useful in treating ulcers, vesicles, boils, skin diseases and eye disorders. The leaves extracts against breast tumors. Drinking jasmine tea regularly helps in curing cancer. Other uses: Jasmine oil is used for making perfumes and incense. Its flowers are used to flavor. Its oil is also used in creams, shampoos and soaps. In India, the Jasmine flowers are stringed together to make garlands. Women in India wear this flower in their hair. Some communities use this flower even to cover the face of the bridegroom. In value addition it is used for making garlands, veni, bouquets, perfumes, etc are considered. The asparagus and calotropis flowers are used as fillers. People use the jasmine flowers as religious offering to the Gods like Lord Shiva and Lord Vishnu. It is the National Flower of Tunisia and Indonesia.

Yield: Flower and concrete yield in jasmine varies considerably according to the species and cultivars, management practices, etc. [1]

\begin{tabular}{|c|c|c|c|}
\hline Species & Flower yield (kg/ha) & Concrete recovery (\%) & $\begin{array}{c}\text { Concrete recovery } \\
\text { (kg/ha) }\end{array}$ \\
\hline Jasminum sambac & $740-6,900$ & $0.12-0.19$ & $1.18-11.88$ \\
\hline Jasminum auriculatum & $4,700-9,100$ & $0.28-0.36$ & $14.20-25.63$ \\
\hline Jasminum grandiflorum & $4,320-10,140$ & $0.28-0.32$ & $13.85-29.42$ \\
\hline
\end{tabular}

Jasminum grandiflorum 'CO-2 Pitchi’ yields $11,600 \mathrm{~kg}$ flowers per hectare. 
Pest and Diseases: Budworms are sometimes problems in jasmines. They can be effectively controlled by spraying Nuvacron $(0.2 \%)$. Leaf spot is reported to be a serious malady affecting jasmines. A broad spectrum fungicide like Dithane M 45 is effective in controlling leaf spot. Nematode infections and root rot diseases are also noticed.

Essential Oil Extraction: Volatile solvent extraction method is common method adopted. Flowers soaked in food grade hexane (boiling point $70^{\circ} \mathrm{C}$ ). Then, mix hexane $21 / \mathrm{kg}$ of flowers for 30 minutes. Rotate container slowly for 20 minutes. Perfume substance along with wax and pigments dissolved in hexane solvent. Perfume laden solvent is led into the evaporator. Evaporation was at a constant temp $\left(75^{\circ} \mathrm{C}\right)$. Vapor of the solvent condensed into liquid for recycling. Liquid distilled into vacuum distillation unit for complete removal of solvent in the sill. Floral concrete settled in the sill in the form of molten wax. Cooled and stored in glass or $\mathrm{Al}$ containers.

Marketing: The methods of marketing is depends on production season, arrival of flowers, volume of flowers handling, price fluctuation of flowers. The merits and drawbacks in flower market is varies place to place. Street vending of jasmine flower is very common. They can be seen in street corners and near strategic places such as temples in cities and towns. They are also sold in the organized market and shops. A large factory generally extracting essence from jasmine, contacts the growers directly for regular supply in required quantities. The intermediaries most commonly observed in the marketing of jasmine flowers are commission agents, wholesalers, retailers and vendors. Commission agents generally finance growers. The commission agents and wholesalers are the main actors in the movement of flowers between the major markets.

Transporting: Flowers are transported between markets to bridge the gap between supply and demand positions in different regions. No time should be lost in transporting flowers after harvest. Jasmine flowers are transported by air, road and rail. Jasmine is shipped regularly by air from Madurai and Coimbatore to Bangalore, Kochi and Mumbai. Flowers are also transported by road and rail over long distances. Trucks, tempos and buses are used for transportation by road. The sources of supply of jasmine are cities in Karnataka, Tamil Nadu, Maharashtra and west Bengal. The major destination again is Mumbai. There is considerable exchange of shipments between Karnataka and Tamil Nadu. The other destinations of jasmine are cities in Kerala, Bihar, Uttar Pradesh, Orissa and Gujarat.

Export Promotion: Export procedures in India includes-exporter, export packaging, cargo booking and logistics to airport (domestic), plant quarantine certificate, customs clearing, airlifting to foreign, consignment clearing and reach to the client. Value chain on jasmine and its constraints in flower business are the open field cultivation, quantity variation, quality and price fluctuation, etc. considered as main.

\section{Conclusions}

The jasmine is a high capital intensive crop and its cultivation is quite profitable. The investment in jasmine is economically feasible and financially sound. Jasmine is labor-intensive crop, it provide more than 1,300 man days labor per year.

\section{Constrains}

The jasmine is a high capital intensive crop. Due to short span of life of harvested flowers, the growers often face the problem of storage in the peak season of flowering. No time should be lost in transporting flowers after harvest. It lacks of essential oil unit in the villages for extraction of essential oil.

\section{Road Ahead}

There is a need to improve the extension mechanism, which at present is still weak and lacks floriculture orientation and gender sensitivity.

\section{REFERENCES}

[1] Bhattacharjee, S. K. (2006). Advances in Ornamental Horticulture. pp 84-109.

[2] Bhattacharjee, S. K. and Lakshman Chandra De. Advanced Commercial Floriculture. Avaishkar Publishers, Distributors Jaipur. pp. 388-389.

[3] Lakshman Chandra De (2011). Value addition in flowers and orchids. New India Publishing agency, New Delhi. pp. 1-22.

[4] Subramanian, S and Kannappan, K. (2002). Studies the effect of growth regulators on off season flowering production in Jasminum sambac (In) Abstract of National Symposium on Indian floriculture in the New Millenium Feb 25-2. Organized by Indian Society of Ornamental Horticulture and National Horticulture Board. P. 42. 